\title{
The Spatial Development of the Territories in the Context of Digitalization
}

\author{
Olga Dovydova \\ School of Management \\ Belarus State Economic University \\ Minsk, Belarus \\ olgadov@tut.by
}

\author{
Nina Stoma \\ School of Management \\ Belarus State Economic University \\ Minsk, Belarus \\ olgadov@tut.by
}

\begin{abstract}
The article examines the impact of digital innovation on the spatial development of territories. In the course of the work, the main directions of the digital transformation of the economy and territorial development were identified through the introduction of new innovative technologies and the construction of a digital society. The main advantages and prospects, as well as the risks and problems faced by the Republic of Belarus on the way to increasing the sustainable development of the digital space, are highlighted. In the practical part of the study, the dynamics of the urban population of the Republic of Belarus, the dynamics of migration within the countries were analyzed and the basic data for the city of Minsk were analyzed. In the final part of the article, the directions of the future spatial development of territories in the context of digitalization are given. The analysis of the dynamics of the information and communication infrastructure and digital infrastructure of the Republic of Belarus is carried out. The conclusion is formulated that it is necessary to create conditions for the effective implementation of digital technologies in the development of the country's territories in order to ensure the transition to new standards of quality of life of the population.
\end{abstract}

Keywords-Spatial development of territories, digital technologies, digital society, innovation, smart city, digitalization.

\section{INTRODUCTION}

The development of the economic space largely determines the security and competitiveness of the state, so the goal of introducing digital technologies is to accelerate the development of all its territories and ensure a decent standard of living for the country's population on this basis [1].

The digital economy is a promising reality, which is a complex integrated system of flexible technologies and communications of an intelligent society that provides solutions to current economic problems that modern society seeks to implement.
The main features of the digital economy are continuous development, change, increased flexibility, adaptability, information exchange and real-time operations and a selflearning digital society. Digitalization is changing the national economy, and it is obvious that its impact is very significant [2].

\subsection{Related Work}

The Republic of Belarus is purposefully implementing the concept of creating a digital economy, actively introducing advanced information and telecommunications technologies, creating «smart cities» and networks [3].

However, it is worth noting that there are a number of problems that the Republic of Belarus faces when building a digital economy and a «digital» society.

There is a decrease in the rate of filling patent applications and issuing patents, which is a negative factor in innovation and indicates a lack of involvement of researchers and practitioners in the creation of new inventions, utility models and industrial designs. This also indicates a generally low level of innovation activity and, as a result, indicates unfavorable conditions for conducting scientific research [4]

For world powers, it is of particular importance to create conditions for the transition to rational models of production and consumption in the regional economy using digital technologies, promising specialization and cooperation.

In the Republic of Belarus, the low readiness of industrial production for digital transformation and the production of innovative products will be observed until a number of issues are resolved to improve the organization of enterprises and create favorable conditions for the development of innovation activity [5].

The strategic goal of regional policy is the comprehensive development of each region and the reduction of existing regional differences, taking into account the effective use of its resource potential and competitive advantages in the interests of ensuring a high standard of living for the population, nature conservation, as well as the positive contribution of regions to national competitiveness and security. 
The state of digital transformation in the industrial sector can be studied on the example of indicators of industrial production by the level of technology, as well as gross value added (hereinafter-GVA) of the largest segment - the manufacturing industry.

The state is interested in increasing the GVA as a source of filling the budget, as well as employees, since wages are an integral part of this indicator. Entrepreneurs are interested in profit, which is also included in the GVA, since it creates conditions for expanding production [5].

The strategic goal of improving the distribution of productive forces is to diversify the economic structure and employment of regions and cities, overcome infrastructure and institutional constraints in the socio-economic development of territories, reduce territorial disparities in the level and quality of life of the population and, ultimately, increase production efficiency in accordance with the requirements of the «green economy» [6]

Therefore, it is important to form an innovative-thinking, proactive, and ready for entrepreneurial risk and active participation in the development of territories community. A special role in the implementation of this task is assigned to the improvement of the regional educational environment in the interests of sustainable development, personal growth and the realization of individual abilities [7].

High-tech production allows you to create products with the highest added value, thereby creating positive factors for the sale of such goods and services. It is necessary to adhere to the principle of concentration of resources in the areas of current and future specialization, complexity and balance of development, taking into account the role, needs and capabilities of each of the administrative-territorial units included in the territorialeconomic complex [4].

In modern conditions, scientific and technological progress, innovation and investment climate are the most important factors of economic growth in the territories of the Republic of Belarus. There is no other source of wage growth in the country other than increased productivity. However, the growth of labor productivity, quality of life and well-being of the population is impossible without new technologies, innovations and investments.

The success of the innovation process largely depends on how many its direct participants - scientists, engineers, designers and employees - are interested in the rapid and cost-effective implementation of research and development results in production. Work motivation of employees and stimulating their high-performance work is crucial [8].

The introduction of innovations should be reflected in the receipt of economic profit as a source of motivation for innovative activities of the enterprise's personnel and within the framework of added value, allocate an innovative motivation Fund. In agreement with the owners, the profit received from innovation activities should be partially credited to the Fund for motivation, creation and implementation of the bonus system from the economic profit [8].

Thus, we can conclude that the goal of the stateinnovative development program is to improve the conditions that contribute to the transformation of human activity under the influence of information and communication technologies, including the formation of the digital economy, the development of the information society and the improvement of e-government [6].
It can be noted that new types of products and industries based on digitalization are emerging in developed countries, such as [9]:

«Smart equipment». Providing various types of equipment and machines with automated systems that interact with cloud platforms allows you to provide users with useful services rather than just hardware.

«Smart home» allows you to manage the life cycle of a building based on a digital model of the building, reduce energy costs and provide additional services to residents

«Smart city» allows you to manage urban infrastructure (transport, power supply, security) based on a digital geographic information model.

Many cities are actively involved in modernizing and reengineering public processes and services, and have achieved good results by simplifying management and improving efficiency, effectiveness, and outreach [10]. However, in the process of digital transformation, cities face many challenges, including rethinking governance, allocating resources for retraining and introducing new technologies, as well as legislative and policy issues.

Digitalization can reduce operating costs, but organizations need to adapt to the impact that digitalization has on jobs, as digitalization results in a reduction in staff. In addition, the lack of qualified personnel is one of the key constraints for the implementation of digital solutions in the economy sectors. Existing employees need new skills to adapt processes to the digital age and work effectively [7].

The introduction of digital solutions reduces the time and cost of obtaining information and conducting administrative procedures. As a result of digitalization, there is an increase in service consumption, and the population uses the collected data to improve services or in decision-making processes. Free access to the best information databases in the world is an integral part of education and health systems, business communications and communications.

Therefore, it is no accident that the focus is on a special innovative economic process based on the sustainable development of digitalization in order to constantly search for new opportunities to increase competitiveness, focus on innovation as a result of the practical use of cluster innovations in the mode of spatial economic development [10].

Ultimately, the strategy of digitalization of the economy contributes to expanding the scale of exchange production, increasing the market value of enterprises, more efficient use of means of production and labor, both in the field of material production and in the service sector, and most importantly, increasing competition and changing the existing business style [9].

Thus, the processes of digitalization of economic activity within territorial zones are stimulated and a high level of their competitiveness and the country as a whole is ensured.It is fair to evaluate the real values of indicators that reflect the economy's transition to digitalization.

\section{MAIN PART}

The dynamics of indicators of the information and communication infrastructure of the Republic of Belarus over the past five years is presented in Table 1 [12]. 
TABLE I. DYNAMICS OF INFORMATION AND COMMUNICATION INFRASTRUCTURE FOR 2015-2019

\begin{tabular}{|c|c|c|c|c|c|}
\hline Name of the indicators & 2015 & 2016 & 2017 & 2018 & 2019 \\
\hline $\begin{array}{c}\text { Number of subscribers and users of wireless broadband Internet access per } 100 \text { population, } \\
\text { percent }\end{array}$ & 60 & 67 & 76 & 86 & 90 \\
\hline $\begin{array}{l}\text { Proportion of the population aged } 6-72 \text { years using the Internet in the total population aged 6- } \\
72 \text { years, percent }\end{array}$ & 67.3 & 71.1 & 74.4 & 79.1 & 82.8 \\
\hline Population of the Republic of Belarus, thous. & 9480,9 & 9498,4 & 9504,7 & 9491,8 & 9408,4 \\
\hline
\end{tabular}

Compared to 2015, the number of Internet subscribers and users increased by one and a half times, despite the reduction in the population over the reporting period. According to calculations, for the period of 2019, the number of subscribers in the whole country is 8467.56 people, while in $2015-5645.34$ people.

There is also a positive trend in the percentage of the population aged 6-72 years who use the Internet-an increase of 15.5 percentage points. The figure in terms of population for the period 2019 is 7,790.15 people, and in $2015-6,380.64$ people.
This indicates an increase in the number of people who have access to and use the Internet. It is worth noting that there is a positive trend in the share of the population aged 6 to 72 years using the Internet, which reflects the expansion of the user audience, the introduction of digital technologies to the masses, their adaptability and use by different age groups.

It is worth paying attention to the indicators that reflect the digital infrastructure: the dynamics of the provision of public electronic services, the share of educational institutions using digital technologies, and the share of doctors in public organizations.

These data are presented in Table 2 [12].

TABLE II. DYNAMICS OF THE DIGITAL INFRASTRUCTURE OF THE REPUBLIC OF BELARUS FOR 2016-2019

\begin{tabular}{|c|c|c|c|c|}
\hline Name of the indicators & 2016 & 2017 & 2018 & 2019 \\
\hline Number of state e-government services rendered per 100 people of the population, units & 14 & 27 & 54 & 55 \\
\hline The share of educational institutions covered by the e-school project in the total number of educational institutions, & 2,5 & 16,4 & 16,4 & 59,0 \\
\hline
\end{tabular}

Data analysis has shown that the number of state electronic resources provided has almost tripled. The growth rate was $292.8 \%$. This dynamic reflects the positive dynamics of e-government development, which has a positive impact on optimizing data processing, data storage, public services, and improving the quality and security of government agencies. The creation of e-government has improved the quality of services for citizens and businesses.

The share of educational institutions also increased significantly during the study period and is $59 \%$ of the total number of institutions, which is already more than half of the total number. Over the period 2016-2018, the growth rate was $2260 \%$ (the share increased almost 23 times). The dynamics are positive, and the introduction of digital technologies in the educational process brings many advantages. These include access to additional information, developing principles for independent learning and searching for information, and creating creative prerequisites for completing tasks and studying the material.

Statistics provide data on the level of adaptation to the digital transformation of educational institutions covered by the E-school project, but in addition, many higher education institutions are also switching to the use of online and electronic resources.

Positive dynamics of development was also observed in the healthcare sector. The growth rate of the share of doctors who can use electronic technologies in working with patients was $281.2 \%$. it should be noted that recently the introduction of digital technologies has been observed at all levels of health care - electronic queues, electronic cards and data warehouses, electronic statements, and even the possibility of online consultations with specialists of narrow specializations.

The general conclusion about the dynamics of the level of digitalization of infrastructure can be considered the conclusion that all indicators have high growth rates, and the achievements of digital transformation are becoming publicly available to the population and become an integral part of everyday life.

It is worth noting that the new direction of urban development is based on the principle of using traditional networks and services, which makes them more effective with the use of digital and telecommunications technologies in the interests of their residents and businesses. Digitalization of cities and districts increases the use of unused material, labor, and financial resources [13].

A smart city goes beyond using information and communication technologies to use resources more efficiently and reduce emissions. This means smarter urban transport networks, improved water and waste management systems, and more efficient ways to light and heat buildings. It also means a more interactive and responsive city administration, safer public spaces, and meeting the needs of an aging population [14].

To address the issue of economic development and activation of enterprises in a certain territory, the introduction of digital technologies is relevant.

The necessity and expediency of stimulating innovative activity of personnel, changing the structure and technology of the organization necessitates the introduction of a flexible remuneration system that corresponds to a new type of 
industrial relations and allows you to find a compromise between employers and employees [5, 8]. Innovations should be reflected in the economic profit as a source of motivation for innovative activities of the organization's personnel.

In modern conditions, it is proposed to adopt two types of assessments of the effectiveness of innovations [8]:

1. Thanks to innovations, organizations are brought out of unprofitable or unprofitable state (below Bank interest on deposits) to the level of normal profit.

2. Through innovation, organizations with normal profits begin to make economic profits.

In both cases, part of the profit can be used to encourage participants in innovation.

The recommended algorithm for making a decision on the size of the innovation motivation Fund includes the following steps [8]:

1. Formation of the wage Fund (payroll account) based on the marginal productivity of labor;

2. Analysis of the actual Federal budget and the actual number of employees and making a decision on the planned number;

3. Formation of normal and forecasted profit taking into account Bank interest and current profitability;

4. Formation of the actual and planned ratio of the wage Fund and profit in value added;

5. Making a decision on the final establishment of the ratio between the wage Fund and the profit in value added;
6. Allocation of the Fund for motivation of innovative activity of employees of the enterprise.

The problem of market transformation through the introduction of digital technologies as a way to improve the efficiency of territorial development is an urgent topic of scientific research. Strategic issues related to the introduction of digital technologies have been actively discussed at the government level over the past decade [9].

Priorities of territorial development of the space based on digital technology are: sustainable urban mobility and built environment, integrated infrastructures and processes in energy, ICT and transport; integrated planning and management; knowledge exchange; develop and implement integrated solutions; support networking, partnerships and information exchange.It is planned to introduce new standards of urban planning and intelligent life support management systems based on modern information and communication technologies [15]. Among them-the formation of a balanced, safe, comfortable and inexpensive transport system for consumers in cities, the development of urban services and the economy of shared consumption with increasing the efficiency of services, increases the useful life of material assets.

Next, we analyze the dynamics of the urban population of the Republic of Belarus and study the dynamics of migration within the country.

Data on the population of the Republic of Belarus for 2010-2019 are presented in Table 3 [12]

TABLE III. POPULATION OF THE REPUBLIC OF BELARUS FOR 2010-2019

\begin{tabular}{|c|c|c|c|c|c|}
\hline \multirow{2}{*}{ Year } & \multirow{2}{*}{ Total population, thous. } & \multicolumn{2}{|c|}{ Of which } & \multicolumn{2}{|c|}{ Of total population, percent } \\
\hline & & urban & rural & Urban & rural \\
\hline 2010 & 9500.0 & 7077.1 & 2422.9 & 74.5 & 25.5 \\
\hline 2015 & 9480.9 & 7325.0 & 2155.9 & 77.3 & 22.7 \\
\hline 2017 & 9504.7 & 7400.8 & 2103.9 & 77.9 & 22.1 \\
\hline 2018 & 9491.8 & 7412.1 & 2079.7 & 78.1 & 21.9 \\
\hline 2019 & 9475.8 & 7429.2 & 2046.0 & 78.4 & 21.6 \\
\hline
\end{tabular}

The Republic of Belarus has been experiencing cyclical population dynamics for 10 years. However, despite this fact, the urban population has a positive dynamic - the growth rate for the study period was $4.9 \%$, and the increase in the share of the total population left 3.9 percentage points. Considering the unstable dynamics of population growth, it should be noted that the total share of the urban population increased by 3.9 percentage points compared to 2010 .

Thus, we can conclude that the increase in the urban population is due to such factors of attraction as developed infrastructure, higher incomes, comfortable conditions, developed transport infrastructure, high-speed Internet access, the ability to work in remote access mode and receive additional education, a high level of mobile services and the use of information technologies.

You can also study the dynamics of inter-regional migration in 2018 to analyze the movement of the population on the territory of the Republic of Belarus [12]. As of 2018, the number of departures / arrivals was 236,821 , from the city
$-161,989$, which is $68.4 \%$ of all departures, and from rural areas $-74,832(31.6 \%)$, respectively.

If you follow the dynamics of movement by region, Minsk is the leader in the number of arrivals and accounts for $17.3 \%$ of the total population, while the number of departures was $19.5 \%$. It should be noted that population movement is carried out in all regions, but the largest part of departures and arrivals of people falls on the population of Minsk and the Minsk region.

Among the developed cities of the Republic of Belarus, capital and regional cities are distinguished. For the purposes of the study, Minsk was chosen to demonstrate by example that the introduction of digital technologies and state support for the spatial development of the territory, taking into account the latest trends, can bring the urban infrastructure to a new level. Minsk is an independent administrativeterritorial unit with a special status. The main goal of socioeconomic development of the city until 2020 is to improve the welfare and living conditions of the population by 
increasing the competitiveness of the economy, activating market institutions and innovative development, and ensuring social stability [16].

To achieve these goals, the priority directions of Minsk's development are to increase the efficiency of investments, create new jobs, increase and diversify exports, accelerate informatization, and form a motivated, educated and active generation.

Such activities as" information and communication activities", financial and insurance activities"," professional, scientific and technical activities» have the maximum potential for the socio-economic development of the city [17].
It is worth noting that setting urban development goals has a positive impact on the overall structure of the country's development.

Thus, the volume of Minsk's gross regional product in January-September 2020 compared to the same period of the previous year in comparable prices amounted to $98.4 \%$. $27.8 \%$ of the Republic's GDP is formed in the capital, and the share in the Republic's foreign trade turnover is 34.8\%.The main data on the level of development for January-September 2019-2020 in Minsk are presented in Table 4 [12].

TABLE IV. MAIN INDICATORS OF MINSK CITY DEVELOPMENT

\begin{tabular}{|c|c|c|}
\hline Name of the indicators & $\begin{array}{c}\text { January- } \\
\text { September } \\
\mathbf{2 0 2 0}\end{array}$ & $\begin{array}{c}\text { January- } \\
\text { September } \\
2019\end{array}$ \\
\hline Number of people employed in the economy, people & 1085671 & 1086136 \\
\hline Gross regional product, million rubles & 29662,4 & 26042,2 \\
\hline as a percentage of the corresponding period of the previous year & 98,4 & 100,9 \\
\hline The specific weight of the GRP of Minsk in GDP, $\%$ & 27,8 & 26,9 \\
\hline Volume of industrial production, million rubles & 13671,5 & 12635,7 \\
\hline in percentage of the national volume of industrial production & 16,5 & 14,7 \\
\hline Share of shipped innovative products in the total volume of shipped products, $\%$ & 18,8 & 18,2 \\
\hline Nominal accrued average monthly salary, rubles & 1733,8 & 1497,3 \\
\hline as a percentage of the national level & 142,3 & 140,1 \\
\hline
\end{tabular}

Urban and rural development is a priority area for spatial development of territories. The program of the National strategy for sustainable development provides for the following measures to improve the territorial development of rural territories: intensive reduction of the demographic and labor gap with developed territories, creating conditions for increasing incomes and quality of life of the population, improving the efficiency of agriculture, using local resources and developing the service sector [14].

\section{CONCLUSION}

Thus, we can conclude that it is necessary to create conditions for the effective implementation of digital technologies in the development of the country's territories in order to ensure the transition to new standards of quality of life of the population. The properties of digital technologies allow us to solve current social and global problems using information and communication technologies, simplifying communication between science, business, government and civil society [18].

The development of territories using information technologies creates a new digital space, providing the population with access to a significant array of digital data through the use of digital technologies, digital infrastructure and services, technologies for analyzing large amounts of data and forecasting to optimize production, distribution, exchange, consumption of material goods and increase the level of socio-economic development [19].

Digitalization forms the rules for digital business participants, which allows cluster forces to unite and almost instantly transfer the system from one state to another, as well as act as strategic tools for forecasting and optimal choice of innovative entrepreneurship.
Smart cities are becoming the growth pole of the digital economy, supporting the competitiveness of regional economies, and through them-national economies that create the latest digital resources to ensure the openness of the economy and improve the quality of economic growth.

Special attention should be given to placement in small and medium-sized cities small industries with export potential with the integrated use of natural resources, scientific-technical potential of the enterprise and the location of new plants based on the processes of urbanization and projected demographic situation.

It is necessary to attract additional resources for research and development based on the participation of stakeholders and to strengthen the innovative focus of foreign direct investment [15].

The state should support organizations that produce hightech products and ensure the development of a multi-level innovation infrastructure, including regional educational complexes, technology parks, business incubators, business support centers, and technology transfer centers that ensure the commercialization and materialization of scientific achievements.

Digitalization of the economy and society increases labor productivity, creates new opportunities for entrepreneurship and labor, increases the level of education and constantly expands professional qualifications, creating new opportunities for socially significant and research areas of development.

\section{ACKNOWLEDGMENT}

The results of the work were discussed at various international scientific and practical conferences, and some developments were tested at international competitions and 
Olympiads. The materials of the work were used in the educational process and have acts of implementation in the educational process. The work was carried out within the framework of the scientific topic "conceptual, methodological and methodological approaches to assessing the impact of the high-tech sector of the economy on economic security in the context of new threats and opportunities for using the integration processes of the CES". 16-2016 B and "methodological approaches and tools for forming the industrial policy of the Republic of Belarus in the CES".

\section{REFERENCES}

[1] V.V. Chernyh, A.P. Suvorova, and R.I. Bazhenov "The digital transformation of economic systems - factor in the strategic development of the territories", Bulletin NGIEI, 2019, no 12 (103), pp. $105-120$.

[2] O.G. Dovydova, "Actual problems of enterprise economics within the framework of innovation potential development of the Republic of Belarus", Management of socio-economic systems: materials of the International scientific-practical conference, Vologda, 2-3 February 2017 / Vologda State University; edited by E.S. Gubanova (Ch. Ed.) [and others]: Vogodsk State University, 2017, pp. 126-129.

[3] On State Innovation Policy and Innovation Activity in the Republic of Belarus, Law of the Republic of Belarus of 10.07.2012, No 425-Z

[4] O.G. Dovydova, "Innovations as a factor in increasing the efficiency of industrial enterprises in the conditions of digitalization of the economy", Problems and prospects of development of the scientific and technological space: materials III-International. scientific practical Internet-conference, Vologda, 24 - 28 June 2019 / Federal State Budgetary Institution of Science "Vologda Scientific Center of the Russian Academy of Sciences"; edited by E.A. Mazilov. Mazilov E.A., (Ch. Ed.) [and others]. In 2 parts. Part II. - Vologda: ISERT RAS, 2019, pp. 231-234.

[5] O.G. Dovydova, "Actual problems of innovation potential development and innovation activity in the Republic of Belarus", Economic and financial mechanisms of innovation development of digital economy: collection of scientific articles. Minsk, 2019. / BSU Institute of Business; edited by V.V. Dovydova. V.V. Puzikova, M.L. Zelenkevich. In 2 p. p. 1. - Minsk: 2019, pp. 22-27.

[6] State program "The Development of Digital Economy and Information Society". DOI: http://economy.gov.by/en/list of sp-en/.

[7] United Nations Human Settlements Programme (UN-Habitat). International Guidelines on Urban and Territorial Planning.URL: https://www.uclg.org/sites/default/files/international guidelines on u rban and territorial planning un habitat.pdf, (assecced 12.09.2020).

[8] O.G. Dovydova, "Evaluation of digitalization of the economy of the Republic of Belarus", Economic growth of the Republic of Belarus: globalization, innovativeness, sustainability: materials of XIII International scientific conference, May 14, 2020 / Belarusian State Econ. unit; edited by V.Y. Shutilin (Ch.) [et al.] - Minsk: BSEU, 2020, pp. 85-86.

[9] Measuring digital development: Facts and figures, 2019, DOI:https://www.itu.int/en/ ITUD/Statistics/ Pages/facts/default.aspx.

[10] European Commission website//What are smart cities?. DOI https://ec.europa.eu/info/eu-regional-and-urbandevelopment/topics/cities-and-urban-development/cityinitiatives/smart-cities_en

[11] What is digitalization and what areas of life will it affect. DOI: https://center2m.ru/digitalization-technologies

[12] National Statistical Committee of the Republic of Belarus. DOI: https://www.belstat.gov.by

[13] M. Angelidou, "Smart City characteristics and their role in fifteen cases of Smart City plans", Journal of Urban Technology, 2017, No.4, pp. 3 28.

[14] The National Strategy for Sustainable Socio-Economic Development of the Republic of Belarus until 2020 (NSSD-2020) DIO:https://www.oneplanetnetwork.org/sites/default/files/belarus_nat ional_strategy_for_sd_to_2020.pdf

[15] S. Grumbach, "Digital Platforms: A New Grammar for Territories?". DOI:
https://www.researchgate.net/publication/321992793_Digital_Platfor ms_A_New_Grammar_for_Territories/citation/download

[16] President's decree Republic of Belarus 31.01.2017 № 31’, State program of innovative development of the Republic of Belarus for 2016-2020. DIO: http://gknt.gov.by/en/news/2018/state-program-ofinnovative-development-of-republic-of-belarus-to-becomprehensively-amended/.

[17] S.V. Kadomceva, and I.V. Manahova, "Sovremennayaparadigmasocial'no-ekonomicheskogo razvitiya". Chast' I. Informatsionnayarevolyutsiya [The modern paradigm of socio-economic development. Part I. Information revolution], Vestnik Saratovskogo gosudarstvennogo social'no-ekonomicheskogo universiteta [Bulletin of the Saratov State Socio-Economic University], 2017, No. 5 (69), pp. 17-23.

[18] System "Science - Technology - Innovation": Methodology, Experience, Prospects: a collection of articles of the International scientific conference in the framework of the International Congress "Science - Knowledge Economy", Minsk, 26 - 27 October 2017 / Center for System Analysis and Strategic Studies of NAS of Belarus, edited by V.V. - Vologda: VSU, 2017. V.V. Goncharov (Ch. Ed.). V.V. Goncharov (Ed.), Minsk, 2017, pp. 366-370.

[19] Spatial Planning, Territorial Development, and Territorial Impact Assessment.

DOI: https://journals.sagepub.com/doi/abs/10.1177/0885412219831375?jo urnalCode=jplb 